\title{
Hobbes and the Question of Power
}

\author{
SANDRA FIELD*
}

THE QUESTION OF POWER IS CENTRAL to the study of politics. Thomas Hobbes has been hailed as the author of the greatest political philosophy written in the English language, ${ }^{\mathrm{I}}$ and indeed as the philosopher of power par excellence. ${ }^{2}$ Nonetheless, I argue that conceptualizing political power is a problem for Hobbes. He starts with a commonsense view that understands the power of individuals as their natural faculties, and that then envisages these powers being compounded together by covenant to form the power of a commonwealth. However, I argue that between his early and late texts, ${ }^{3}$ Hobbes finds it necessary to modify his account, in three respects. First, individual power is reconceived as a socially constituted capacity, potentially unrelated to natural faculties; second, human powers are now understood constantly to form combinations, even without covenant; and third, a distinction emerges between the causal capacity (potentia) and the authority (potestas/imperium) of the sovereign, where these had previously been conflated. ${ }^{4}$

Hobbes wrote his works during a period of political ferment; there will surely be an illuminating contextual story that can be told to explain his changed view of political power. However, rather than reconstituting this external historical causality, my argument focuses on the internal conceptual difficulties of the earlier view, and how they are overcome in the later one. The threefold change in the concept of political power reflects a changed diagnosis of the problem of politics. It is not enough to defend a doctrine of the authorized power of the sovereign; such a

\footnotetext{
${ }^{\mathrm{I}}$ Oakeshott, "Introduction," viii.

${ }^{2}$ Macpherson, "Introduction," 9-IO. For Oakeshott, "Hobbes's philosophy is, in all its parts, preeminently a philosophy of power" ("Introduction," xxi).

${ }^{3}$ For the purposes of this paper, I consider Hobbes's early political works to be The Elements of Law (I640) and De cive (I642), and his late political works to be Leviathan, both the English (I65I) and Latin (I668) editions.

4Although in English this distinction is obscured under the single term 'power,' nonetheless I am able to differentiate between the concepts even in the English texts by comparison of passages, most directly between the English and Latin Leviathan.
}

* Sandra Field is Assistant Professor of Humanities at Yale-NUS College. 
doctrine must be robustly complemented by an account of how the effective power commensurate to this authority might be achieved. 5 Nor is this straightforward: for effective political power is not a stable object of possession; rather, it can vary, sometimes severely. Hobbes's Leviathan $(L)$ takes significant steps to correct his earlier texts' preoccupation with power as entitlement and neglect of effective power. ${ }^{6}$ In this light, the prevalent juridical ${ }^{7}$ accounts of Hobbes's political philosophy are inadequate. ${ }^{8}$

In this first part of the paper, I reconstruct Hobbes's view of power in his early political works The Elements of Law (EL) and De Cive (DC), establishing three points in particular. First, individual human power is conceived as faculties; second, the only politically salient way in which these powers are combined is via a formal covenant; and third, the power of the sovereign is the result of such a covenant.

\section{I.I}

In his early texts, ${ }^{9}$ Hobbes frequently uses the term 'power' interchangeably with 'faculties.' ${ }^{\text {to }} \mathrm{A}$ human individual's power is "the faculties of body and mind ... that is to say, of the body, nutritive, generative, and motive; and of the mind, knowledge" (EL I.8.4). ${ }^{\text {II }}$ This is not implausible: in common usage power means something like the capacity to do things, and faculties are nothing but the specific capacities belonging to me by which I can do things. However, Hobbes very promptly moves on to make a broader use of the term 'power,' extending it to encompass what I call 'secondary powers':

${ }^{5}$ In an influential paper, Hoekstra explores the sense in which the possession of potentia gives rise to potestas/imperium; he does not explore the reverse problem, of how potentia adequate to potestas might be achieved ("The De Facto Turn in Hobbes's Political Philosophy," 33-35).

${ }^{6}$ Such neglect is not unique to Hobbes's early texts. It is also is evident in contemporary constitutionalism, in the tendency to grasp the power of a particular branch of government or of a church as that power that it is attributed to it legally, via explicit constitutional provision, to the neglect of the question of its effective power. The disparity between these terms is particularly stark when the USA and the UK are juxtaposed: the fact of the establishment of a church in the UK and the explicit antiestablishment principle in the US constitution do not go very far in illuminating the actual ascendency of religion in politics in the two countries.

7I use 'juridical' in a general sense to mean concerned with power as authority, not in a more specific sense to mean concerned with law, positive or otherwise.

${ }^{8}$ The dominant interpretation of Hobbes's texts understands his doctrine of sovereign power entirely as a doctrine of authorized power. For instance, Baumgold, Hobbes's Political Theory; Hampton, Hobbes and the Social Contract Tradition; Johnston, The Rhetoric of Leviathan: Thomas Hobbes and the Politics of Cultural Transformation; Martinich, Hobbes; Oakeshott, "Introduction"; Oakeshott, Hobbes on Civil Association; Sorell, Hobbes; Strauss, The Political Philosophy of Hobbes: Its Basis and its Genesis; Tuck, Hobbes; Warrender, The Political Philosophy of Hobbes, His Theory of Obligation; and Watkins, Hobbes's System of Ideas: A Study in the Political Significance of Philosophical Theories.

${ }^{9}$ For this argument, I focus primarily on The Elements of Law. De cive offers only a compressed overview of a science of man, deferring full treatment to De homine (Hobbes, "On Man"; Latin text in Hobbes and Molesworth, Thome Hobbes Malmesburiensis Opera, vol. 2). However, by my periodization, De homine is a later text (post-Leviathan), and consequently not relevant for establishing Hobbes's early view.

${ }^{10} E L$ I.I.4; EL I.I 4.I.

${ }^{11} \mathrm{De}$ cive states that human nature consists in these faculties ( $D C$, Chapter i, Section I). 
[S] uch farther powers, as by them [the faculties of body and mind] are acquired (viz.) riches, place of authority, friendship or favour, and good fortune; which last is really nothing else but the favour of God Almighty. (EL I.8.4)

This extension also remains plausible: many things that I do are done not directly with my natural faculties, but through the mediation of these secondary powers. If I have friends or riches, then it will be easier for me to bring about whatever I want to achieve. But are secondary powers powers in the proper sense? ${ }^{\mathrm{I2}}$ I claim to the contrary, Hobbes's analysis of power always privileges natural faculties, conceiving power as the causal potentiality proper and internal to an individual. Even if Hobbes recognizes secondary powers to be crucially important in human life, they are powers only in a derivative sense, as the conduits for or indicators of faculties. ${ }^{13}$ I demonstrate this claim by considering Hobbes's accounts of equality, honor, and glory.

If secondary powers are powers in the proper sense, then they must factor into the assessment of an individual's power. However, to the contrary, when arguing that people are more or less equal in power, Hobbes does not see it necessary to demonstrate that people's secondary powers, such as the assistance and favor they receive, are equal. Rather, the equality of power is established merely by considering equality in faculties: strength, wit, and knowledge. Correspondingly, the true measure of any inequality of power that does exist is determined not through comparison of secondary powers, but through the clash of bodily strength (EL I.I4.I-5; $D C$ i.3-4, i.6).

Honor is the internal conception of the superiority of another person's power. ${ }^{14}$ The signs ${ }^{15}$ by which power or its excess above that of others can be recognized are called honorable. They include not only the direct effects of a power, but also effects at several causal steps away from that power, by which its existence is indirectly inferred. For instance, "general reputation amongst those of the other sex" is honorable as a sign directly consequent of "power generative"; boldness is honorable via a more indirect signification: it is "a sign consequent of opinion of our own strength: and that opinion a sign of the strength itself" (EL I.8.5). If secondary powers are powers in the proper sense, then their superiority should merit honor, even without reference to faculties. However, to the contrary, whenever Hobbes proposes superiority of secondary powers to be honorable, he takes care

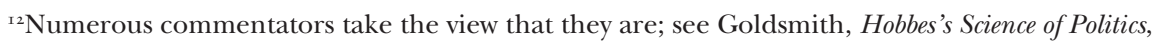
66-7 I; Hindess, Discourses of Power: From Hobbes to Foucault, 24-25; Lazzeri, "Les racines de la volonté de puissance: le 'passage' de Machiavel à Hobbes," 236-45; Macpherson, The Political Theory of Possessive Individualism: Hobbes to Locke, 35-46; Pettit, Made with Words: Hobbes on Language, Mind, and Politics, 92-95; Read, "Thomas Hobbes: Power in the State of Nature, Power in Civil Society," 505-6; Spragens, The Politics of Motion: The World of Thomas Hobbes, I IO-I I; and Warrender, The Political Theory of Hobbes: His Theory of Obligation, 3 I 2-1 3 .

${ }^{13}$ While most of De cive aligns with this analysis, the third theological part does not, aligning more closely with the analysis of the later texts; contrast, for instance, $D C$ i.2-3 with $D C$ xv. I 3 .

${ }^{14}$ This could be superiority compared to the power of the beholder, but it could equally be superiority compared to the average. For instance, a powerful individual can honor their subordinate by praising them (EL I.8.6).

${ }^{15} \mathrm{~A}$ sign is a thing that a person has experienced as regularly occurring antecedent or consequent to something else, which they conjecture will occur in this combination again in the future (EL I.4.9-IO). 
to trace the chain of signification back to an individual's possession of a faculty. Riches are honorable, not because they themselves are power, but "as signs of the power that acquired them"; authority is honorable, not because it itself is a power, but "because a sign of strength, wisdom, favour or riches by which it is attained" (EL I.8.5). Hobbes does not discuss friendship per se, but he does analyze some attributes thereof, again reducing them back to faculties: persuasiveness is honorable, as a sign of knowledge; "general reputation amongst those of the other sex" is honorable, as a sign of bodily vigor ( $E L$ I.8.5).

If secondary powers are powers in the proper sense, then it is not vain to glory in them. Glory,

or internal gloriation or triumph of the mind, is that passion which proceedeth from the imagination or conception of our own power, above the power of him that contendeth with us. (EL I.9.I)

A person has reason to glory when their feeling of superiority of power is grounded in reality, whereas vainglory is the feeling without the real power. However, Hobbes directly denies that association with others gives rise to justifiable glory. " $[\mathrm{N}]$ or does association with others increase one's reason for glorying in oneself, since a man is worth as much as he can do without relying on anyone else." ${ }^{6}$ Similarly, Hobbes insists that reliance on fame to achieve glory indicates a lack of power (EL I.9.20). In both cases, the secondary power (association, or the deference and assistance of those who recognize one's fame) is not by itself reason for glory; in other words, it is not a power in the proper sense.

Thus, despite the initial presentation of secondary powers as powers in their own right, they are only incorporated into the analysis insofar as they are reduced back to natural faculties: ${ }^{17}$ they are mere conduits for or indicators of the only things properly called powers, which are natural faculties. ${ }^{18}$

In what I call the "positionality claim," Hobbes asserts that power is intrinsically positional.

And because the power of one man resisteth and hindereth the effects of the power of another: power simply is no more, but the excess of the power of one above that of another. For equal powers oppose, destroy one another; and such their opposition is called contention. (EL I.8.4)

The analytical part of this positionality claim is reiterated and relied upon constantly throughout Hobbes's early texts. ${ }^{19}$ Capacities are only effective in their

${ }^{16}$ Hobbes, On the Citizen, i.2.

${ }^{17}$ There are also other corroborations in the text. First, the definition of secondary powers"such farther powers, as by them are acquired" (EL I.8.4) —already indicates that for something to be a secondary power, it is necessary that it should have a connection to faculties. Second, Hobbes says that power is known by the actions that it produces; he does not countenance that it might be known directly, as would be the case if secondary powers such as riches and friends were themselves truly powers in their own right (EL I.8.5).

${ }^{18}$ Thus, Tuck is mistaken to claim that in the view of The Elements of Law and De cive, "[p] ower is itself a matter of belief, as is shown by his [Hobbes's] discussion of the concepts of glory, false glory and vainglory" (Tuck, "Introduction," On the Citizen, xxi).

${ }^{19}$ Indeed, the analytical part of the positionality claim also reinforces my argument about secondary powers. Friendship is one of the key examples of secondary power. If friendship is properly a power, then it ought to be consistent with the analytical part of the positional claim, according to which if 
excess over one another; if you and I race to grab an apple, but I am faster, then I have the effective capacity to grab the apple. Your capacity, because comparatively inferior, is entirely ineffective. Hobbes elaborates this point in an extended reflection on the analogy between human life and a race (EL I.9.2I). Indeed, his definitions of glory, honor, and the honorable all involve comparison of power. However, even if the positionality claim is indisputably analytically central, there still remains a terminological question. The positionality claim proposes a new use of the word 'power.' Power is no longer an individual's capacity (whether their faculties or also their secondary powers), but rather the excess of their capacity over the capacity of relevant others: for instance, it is the superiority of my strength that is a power, not the strength itself. The terminological question asks, in these early texts, is the term 'power' used equivocally for both these meanings, or is it reserved for one or the other? In fact, the use of the term 'power' to mean noncomparative capacity is clearly dominant in the text. To start, Hobbes frequently characterizes human power as faculties, not as the comparative excess of faculties (EL I.I.4, I.8.4, I.I4.I). Furthermore, glory and honor are defined in terms of the comparative excess of power; if power already meant this comparative excess, Hobbes would need instead to define glory and honor directly in terms of power (EL I.8.5, I.9.I). Similarly, if power were already comparative, Hobbes should not speak of a situation of equal forces as a situation in which there is equal power, but rather no power at all (ELI.I4.3). Thus, throughout the text of The Elements of Law, Hobbes maintains the term 'power' for the faculties: relational comparison is crucial to understanding the outcomes of human power, but it is not built into the concept of power itself.

\section{I.2}

A social ontology is an account of the kinds of entities that exist in the social domain..$^{20}$ The first building block of Hobbes's early social ontology is the idea discussed in section I.I that humans are equal in power; a fuller account can be reconstructed by considering how these equal powers can be combined. Hobbes distinguishes two possible modes of combination. On the one hand, if a number of individuals, each retaining their own distinct will, nonetheless coordinate to act toward a shared end, then this concourse of their wills is called concord, consent or consensio, forming an association or societas. Their wills are temporarily aligned but remain distinct (EL I.I 2.7, I.I9.4; $D C$ v.3-5). On the other hand, if a number of individuals combine their separate wills through a binding and punitively enforced covenant to form a single collective will, then this is called a union (unio, EL I.I 2.8, I.I 9.6; $D C$ v.6-7). The exemplar of a union is the political commonwealth.

something is a power, its effectiveness lies in its excess over that of others. Indeed, it is true that if I have more friends than you, then I can achieve more of my ends. However, consider the relation not between two enemies who compare the size of their bands of friends, but rather between two friends. In friendship, two people's powers combine to generate more effective power rather than cancelling, contrary to the positional claim's requirements. Thus friendship cannot truly be a power. The same reasoning will apply for any informal association: even if such an association is included on the list of secondary powers, Hobbes's analysis shows them not to be powers in the proper sense of the word.

${ }^{20}$ Pettit, "Rawls's Political Ontology," I 57-74. 
In principle, human collectivities can be either mere associations or proper unions. However, I argue that mere associations have no political salience in the early texts. An association may be prompted by "the fear of a present invader, or by the hope of a present conquest, or booty; and endureth as long as that action endureth" (EL I.I9.4) ${ }^{2 \mathrm{I}}$ But it is impossible for such a federation to deliver lasting peace and cooperation, because any unity is rapidly eroded by "differences of purpose and policy or by envy and rivalry."22 To be sure, associations of animals such as bees can be durable; but unlike animal associations, human associations are destabilized by passions of resentment and envy, by competition for scarce goods, and by disagreement on the most prudent way to pursue even ends that are shared (EL I.I9.5; $D C$ v.5).

This dismissal of associations might seem implausible; surely we can think of many groups which are not commonwealths but which are politically significant. At the very least, there will be familial groupings that are relatively stable. At one level, Hobbes accepts this criticism: he admits that his state of nature poses the idea of humans popping up "like mushrooms", ${ }^{23}$ whereas it is more realistic to imagine a state of nature inhabited by families with children and masters with slaves $(D C$ ix $)$. However, Hobbes shows that these allegedly overlooked collectivities themselves have the structure of a union. The canonical way in which a union comes about is by institution: there is an agreement among individuals to establish a sovereign over them who represents them as a single will and whom they obey. However, union can equally be formed by dominion, conquest, or acquisition: an already mighty individual demands that others agree to submit. In both cases, agreement is motivated by individuals' desire for enduring security, and their fear of its disruption; but in the former they feel threatened by each other, whereas in the latter, they fear a conqueror's sword (EL I.I9.I I; $D C$ v.I2). The overwhelming superiority of force of the parent over the child in a family grouping constitutes a union of this latter sort, even if the agreement is not made explicit. It amounts to an implicit covenant of submission from the child, and consequently families are in fact little commonwealths (EL I.I4.I3, II.3.2, II.4.3, II.4.IO; $D C$ ix).

Thus Hobbes's social ontology envisages a thoroughly fragmented social sphere, capable of redemption only through a covenant establishing external unification in the person of a sovereign. But what is the social ontology of the political order beneath the sovereign? Hobbes grants there may well be subordinate unions, but he does not mention associations ( $E L$ I.I9.9; $D C$ v.Io). Associations appear again to be considered lacking in political salience; this view is particularly evident in Hobbes's treatment of sedition. A seditious group is any union or association that does not actively recognize the sovereign and its authority, or worse, that denies it. A discontented multitude can be seditious (EL II.8.2); but they only constitute a real threat to the sovereign if they have "hope of success." Hobbes argues that this hope requires that they cease being a multitude and structure themselves as a

${ }^{21}$ Also EL I.I 9.6; $D C$ v.4. Hobbes stresses the lack of community among humans in contrast to the social nature of animals (EL I.I 9.5; DC v.5).

${ }^{22}$ Hobbes, On the Citizen, v.4.

${ }^{23}$ Hobbes, On the Citizen, viii. I 
union, consciously deciding to join together and act by a single will under a leader (EL II.8.I, II.8.I I $D C$ xii.I I, xiii.I3). For an informal association is not durable enough; it will be subject to the same tendency to dissolution as in the state of nature. The lack of concern with informal groupings is also reflected in Hobbes's strategy for neutralizing the threat to the commonwealth posed by seditious groups. Hobbes offers rhetorical condemnation of would-be leaders of seditious unions, belittling their claim to good judgment (EL II.8.I2-I 5; DCxii.IO-I3), and he recommends to the sovereign that it should deploy harsh punitive measures specifically for the ambitious (EL II.9.7; $D C$ xiii. I 2). Even though there are other factors of discontent that conduce to unrest, ${ }^{24}$ to prevent sedition it is sufficient simply to undercut the formation of unions by targeting their would-be leaders.

\section{I.3}

I now turn to consider the power of the union that is the commonwealth, or what is the same, the power of the sovereign. A natural person's power is her or his faculties; I argue that we can understand the power of the sovereign in the same way. A commonwealth is a union, which is characterized by its possession of a single will. This unity of will allows Hobbes to conceive of the commonwealth as a fictional (artificial) person (EL I.I9.6-8; DC v.6-I2). ${ }^{25}$ Just as a natural person (a human individual) has faculties, Hobbes is happy to attribute faculties to the sovereign. "For the body politic, as it is a fictitious body, so are the faculties and will thereof fictitious also" (EL II.2.4). These faculties are the faculties of the sovereign conceived in its fictional unity; and this fictional unity is constituted by a covenant in which subjects fully transfer their powers (their faculties). Consequently, the power of the sovereign, which is its faculties, is the sum of the powers of all its subjects.

For the power [potentia] of the citizens is the power [potentia] of the commonwealth, that is, his power who holds the sovereignty [summum . . . habet imperium] in the commonwealth. (DC xiii.2) ${ }^{26}$

The natural faculties of individuals cannot literally be transferred, so instead the transfer of faculties consists in obedience to the will of the sovereign. But there are two options for understanding this unification of powers: does the power consist in the fact that subjects obey (in which case it is in principle variable), or does it consist in the obligation of the subjects to obey (in which case it is invariant)? Even though the sovereign's power comes from subjects, the sovereign's power is not variable.

[G] overnment [imperium] is a capacity [potentia], administration of government [administratio gubernandi] is an act [actus]. Power [potentia] is equal in every kind of commonwealth; what differs are the acts, i.e. the motions and actions of the commonwealth. $(D C \mathrm{x} \cdot \mathrm{I} 6)^{27}$

${ }^{24}$ Hobbes recommends some effort to avoid discontent and bad doctrine (EL II.9).

${ }^{25}$ The analogy with the body of a natural person is constantly emphasized. Hobbes speaks of the "body politic" (EL I.I9.8) and the "person civil" (EL II.I.I); the "Order" of The Elements of Law divides the text into a study of men "as persons natural" and men "as a body politic" (EL xiv).

${ }^{26}$ Hobbes, On the Citizen, xiii. 2.

${ }^{27}$ Hobbes, On the Citizen, x.I6. 
This invariability can be understood in light of the grounding of the conception of power in the sovereign's nature as an artificial person. The artificial person is not defined by the degree of cooperation actually achieved; such a reliance on actual convergence would characterize mere association. An artificial person has a stronger unity, bound to the juridical structure of covenant that defines it. Correspondingly, Hobbes consistently talks of the sovereign's power not as the combined faculties of individuals that it is in fact able to deploy, but as the right to those capacities: “[T]o transfer a man's power and strength, is no more than to lay by or relinquish his own right of resisting him to whom he so transferreth it" (EL I.I9.IO). Obedience does not constitute the sovereign's power; but rather it is an entitlement or something owed to the sovereign in virtue of that power (EL II.I.7; $D C$ V.I I, vi.I 3$).^{28}$

However, Hobbes anticipates that this debt will generally be met: he stipulates the sovereign is actually able to secure the transfer of subjects' powers, because its use of fear is effective in bending their wills.

And though the will of man, being not voluntary, but the beginning of voluntary actions, is not subject to deliberation and covenant; yet when a man covenanteth to subject his will to the command of another, he obligeth himself to this, that he resign his strength and means to him, whom he covenanteth to obey; and hereby, he that is to command may by use of all their means and strength, be able by terror thereof, to frame the will of them all to unity and concord amongst themselves (EL I.19.7; my emphasis) ${ }^{29}$

Hobbes concedes that this bending of wills is not perfect: for he envisages that the sword of justice will be needed not only to frighten subjects away from disobedience but also to discipline them when they do disobey (EL II.I.9-IO, II.9.6). Nonetheless, for the most part actual disobedience is presumed not to be too disruptive; it will be a marginal, foolhardy occurrence, not threatening the civil order.

Thus far I have discussed the sovereign's power in the sense of its potentia. Power as potentia is a concept shared across the natural and human domains of Hobbes's science, and has a meaning close to causal capacity. But this is not the only or primary question of political power. Traditionally, when in English one speaks of the power of a commonwealth, this corresponds to the Latin term 'potestas' or 'imperium,' which has the overtone of authorized power, or authority. Indeed, the terms 'sovereign,' 'sovereignty,' and 'sovereign power' are all generally translated as 'summa potestas,' or 'summum imperium,' the highest potestas or imperium..$^{30}$ Nonetheless, for Hobbes's early texts, this is a distinction that makes no practical difference. ${ }^{3 \mathrm{I}}$ The sovereign's potentia is already understood as the juridical transfer of the potentiae of subjects, and this is simply equated with the authority power (potestas/imperium) of the sovereign.

\footnotetext{
${ }^{28} \mathrm{It}$ is incorrect to consider the potentia of the sovereign in these texts as its actual effectiveness toward its ends, as do Johnston (The Rhetoric of Leviathan: Thomas Hobbes and the Politics of Cultural Transformation, 45) and Warrender (The Political Philosophy of Hobbes, His Theory of Obligation, 3 I 2-I3). ${ }^{29}$ See also EL II.I.6.

${ }^{3 \circ}$ Silverthorne, "Political Terms in the Latin of Thomas Hobbes," 506-8.

${ }^{3}$ Silverthorne, "Political Terms in the Latin of Thomas Hobbes," 506-8.
} 
This Authority [Potestas], this Right to give Commands, consists in the fact that each of the citizens has transferred all his own force and power [suam vim et potentiam] to that man or Assembly. (DC v.II) $)^{32}$

The sovereign's summum imperium (sovereign authority) is equivalent to its potentia absoluta (absolute power, $D C$ vi.I7) ${ }^{33}$

2

Throughout his political texts, both early and late, Hobbes aspires to offer a science of politics, that is, to put the study of politics on a sure foundation. In these texts, scientific understanding is characterized in opposition to mere experience or prudence, which simply reports what has occurred or what tends to occur. ${ }^{34}$ Rather, the crucial aspect of science is good definitions (EL I.5.4-I4, I.6.4; L iv.I2-I3, vii.4). For instance, consider the opening discussion of human nature in The Elements of Law:

Man's nature is the sum of his natural faculties and powers, as the faculties of nutrition, motion, generation, sense, reason, etc. For these powers we do unanimously call natural, and are contained in the definition of man, under these words, animal and rational. (EL I.I.4)

A good definition will contain all and only those properties and powers belonging to a given phenomenon considered in its nature, or in other words, not as an isolated particular but as an instance of a larger class. Correspondingly, scientific understanding of a given phenomenon subsumes it under a definition, legitimately abstracting away from any minor empirical aberrations. To understand a circle drawn on paper in front of me, it is important that I understand its principle (that it should be constructed by tracing out points equidistant from a given locus); it is irrelevant that it may have tiny imperfections in the way it is actually drawn $(D C$ Epis. 5, Pref.9). Thus, a Hobbesian science of man investigates not an individual human's causal effectiveness per se, but the causality proper to her or him as laid out in a good definition of her or his nature. ${ }^{35}$ Nonetheless, there are limits to this tolerance: science has to have some connection to the reality it purports to explain. ${ }^{36}$ As with the circle drawn on paper, it is permissible for there to be some small imperfection of the phenomenon compared to its scientific model; but

${ }^{32}$ Hobbes, On the Citizen, v. I I.

${ }^{33}$ Hobbes, On the Citizen, vi.27. See also EL I. I9. I0; DCx. I6.

${ }^{34}$ EL Epis.xv-xvi, I. I.I, I.4.I; DC Epis.4-9, Pref.4, Pref.9, Pref. I 8; $L$, Chapter v, Section I7; $L$ ix.

${ }^{35}$ In this respect, Hobbes's science is similar to the scholastic method, viewing power as potentiality proper to an individual and belonging to it. Indeed, Brandt demonstrates that Hobbes's very early writings are deeply steeped in the Aristotelian system (Thomas Hobbes's Mechanical Conception of Nature, I7). As Spragens puts it, "Hobbes's idea patterns paralleled those of Aristotle to an astonishing degree even as he drastically refashioned their contents" (The Politics of Motion: The World of Thomas Hobbes, 8). More generally, Hobbes's science has been characterized as less experimental that that of his contemporaries: see Anstey, "Experimental Versus Speculative Natural Philosophy," 2 I 5 ; Shapin, Schaffer, and Hobbes, Leviathan and the Air-Pump, 7.

${ }^{36}$ In Oakeshott's view, “[Hobbes's] conception of philosophy as the establishment by reasoning of hypothetical causes saved him from the necessity of observing the caution appropriate to those who deal with facts and events" ("Introduction," xiv). However, on my reading this is unjust. 
this divergence must remain small if the science is to hold its own. ${ }^{37} \mathrm{I}$ argue that Hobbes's later political view in Leviathan finds the aberrations of social and political reality from the causality of faculties to be significant; understanding power as faculties misses the overwhelmingly social determination of the human capacity to achieve ends in the social sphere. This forces a recalibration of his science of man, his social ontology and his science of the commonwealth. ${ }^{38}$

\section{I}

The phenomenon to be explained by the science of man is human behavior; and in light of the science of commonwealth that builds upon it, we see in particular that the science of man is interested in human social and political behavior. Leviathan observes that a person's causal effectiveness is primarily constituted by the aid or forbearance of the informal constellation of people around them. Correspondingly, rather than restrict the ground of individual power to the faculties internal to that individual, I argue that Leviathan offers a new analysis by which human power is a socially constituted and potentially shifting property. ${ }^{39}$ I make this argument primarily on the basis of Leviathan chapter $\mathrm{x}$, a recognizable descendent of the analysis of human power in The Elements of Law (EL I.8). The very close similarity of the two passages has concealed the deep conceptual change

${ }^{37}$ I concede that in the scholastic tradition to which Hobbes is indebted (see n. 35 ), there is one circumstance under which a scientifically rigorous explanation is exempted from the requirement to accord with the actual phenomena whose nature is being explained. For Aquinas, most sciences are theoretical sciences that explain actual phenomena. By contrast, practical sciences do not even purport to do this; for human nature is fallen and so a science of human nature merely explains how humans ought to behave. (For a concise characterization of this distinction, see Matheron, "Spinoza et la décomposition de la politique thomiste: Machiavélisme et utopie," 5 I-54.) However, this exemption does not apply to Hobbes's political works. For in these texts, first, the science of individual human power is not presented as a science of duty but as a science of real capabilities (see section I.I). And second, the divergence at issue in the case of the science of the commonwealth concerns not the divergence between the model and actually existing commonwealths, but between a commonwealth established in accord with Hobbes's model and Hobbes's claim that such a commonwealth will function peacefully (see section I.3).

${ }^{38}$ This has not been noted in existing comparisons of Hobbes's texts, such as Schuhmann, "Leviathan and De cive," 3 I; and Tuck, "Introduction," Leviathan, xxxviii.

${ }^{39}$ Most commentators do not discuss power/potentia at all. The only commentators who detect a change in the analysis of power/ potentia across the texts are Rudolph ("Conflict, Egoism and Power in Hobbes," 73-88); Carmichael (“C. B. Macpherson's 'Hobbes': a Critique,” 36I, 368-69); and McNeilly (The Anatomy of Leviathan, I44-47).

The following commentators do discuss power/potentia as a generalized effective capacity and observe its relational grounding; however, they err in not discerning any difference in the account across Hobbes's texts (or in some cases explicitly denying any such difference): Foisneau, Hobbes et la toute-puissance de Dieu, 202-IO, 6I-62; Frost, Lessons from a Materialist Thinker: Hobbesian Reflections on Ethics and Politics, I3 I-72; Goldsmith, Hobbes's Science of Politics, 63, 66-7I; Kavka, Hobbesian Moral and Political Theory, 93-94; Lazzeri, Droit, pouvoir et liberté : Spinoza critique de Hobbes, 6 I-77, I I 8-2 I; Lazzeri, "Les racines de la volonté de puissance: le 'passage' de Machiavel à Hobbes," 236-45; Macpherson, "Introduction," 34-38; Macpherson, "Leviathan Restored: A Reply to Carmichael," 38 I (an explicit denial of any change); Macpherson, The Political Theory of Possessive Individualism: Hobbes to Locke, 35-46; Pettit, Made with Words: Hobbes on Language, Mind, and Politics, 92-95; Read, "Thomas Hobbes: Power in the State of Nature, Power in Civil Society," 505-6; Spragens, The Politics of Motion: the World of Thomas Hobbes, I IO-I I; Tuck, "The Utopianism of Leviathan," I 29-30; Tuck, "Introduction," On the Citizen, xxi; and Zarka, Hobbes et la pensée politique moderne, I29-34. 
from most interpreters; but the closeness of the passages makes the small changes I identify more significant. ${ }^{\circ}$

Where The Elements of Law defined power as faculties (ELI.8.4), Leviathan opens with a definition of power that enshrines a privilege to effects:

The power [potentia] of a man (to take it universally) is his present means to obtain some future apparent good. ( $L$ x.I)

Secondary powers also find a new definition, supplementing the backward relation to faculties in The Elements of Law (EL I.8.4) with a forward relation to effects. They are now called "instrumental" powers, and are defined as those "which, acquired by these [natural powers] or by fortune, are means and instruments to acquire more" ( $L$ x.2; my emphasis). Because the criterion for being counted as a power points forward to effects, not back to origins, any causal genesis for a power is acceptable: secondary powers are explicitly included in the general definition of power in equal standing with natural faculties $(L \mathrm{x} . \mathrm{I})$.

Are secondary powers still only powers in a derivative sense? To the contrary, I claim that secondary powers are now genuine powers in their own right, and this status is not dependent on any connection to natural faculties. The refusal to privilege faculties and the shift of focus to effects is systematically reflected in examples. Something is honorable if it is a sign of power. In early and late texts alike, nobility or good birth are certainly honorable, but in The Elements of Law, it is by reflection as a sign of power of ancestors (EL I.8.5), whereas in Leviathan it is a sign that one may easily obtain aid ( $L \times .45)$. Riches were previously honorable "as signs of the power that acquired them" (EL I.8.5); now "riches joined with liberality is power, because it procureth friends and servants; without liberality, not so, because in this case they defend not, but expose men to envy, as a prey" ( $L$ x.4).

The definition of power is thus conceptually different, but does it have the same extension? Might it still be the case that human faculties for the most part explain humans' causal efficacy in the social domain? Indeed, according to the account in the early texts, it so happens that secondary powers are usually only generated when there are natural faculties underlying them. If this is correct, then there is no substantive difference between the views, despite the change of definitions. Against this suggestion, I argue that in Leviathan, Hobbes has come to see that some of the most important social and political powers rest on interpersonal effects and a near total disconnection from faculties.

Honor is the key mechanism by which an individual's secondary powers are produced from their faculties. In The Elements of Law, honor is the internal conception of the superiority of another person's power, and it gives rise to certain characteristic external actions (EL I.8.6). If I think someone else is more powerful than me, I will tend to defer to her, obey her, and be polite to her. For this reason, deference, obedience, and politeness are all signs of honor. It is clear that the deference, obedience, and politeness of others increase the honored individual's

${ }^{4 \circ}$ The two passages stand in the same place in the text, after the discussion of the passions and before the establishment of the commonwealth; the internal sequence of the analyses of power are very similar (starting with natural power, then instrumental powers, then honor); many of the same examples are used. 
capacity to achieve her ends, and indeed, this behavior constitutes secondary power (favor and perhaps friendship) for the honored individual. As I argued, in The Elements of Law, an individual is truly worthy of honor only to the extent that she also possess power as a natural faculty. However, the honoring mechanism can malfunction, meaning that secondary powers can arise in the absence of natural faculties. If I defer to someone because I believe her to be superior in power, but I am mistaken in this assessment, my deference is no less real for its faulty grounds. In the early works, such secondary power grounded in error and not linked to faculties falls outside the scope of scientific analysis: they can be considered contingent accidents ${ }^{4}$ that have nothing to do with individual human power. They are secondary powers but only in a degenerate sense; and they are presumed only to be a marginal phenomenon.

The crucial question for Leviathan will be whether this kind of power not grounded in faculties is a central or a marginal phenomenon. It is certainly no longer definitionally marginal. Honor is redefined as the manifestation of the value that we set on one another's power, where value is "not absolute, but a thing dependent on the need and judgment of another" ( $L$ x.I 6-I 7$).^{42}$ This redefinition removes the distinction between proper and degenerate honor, and between proper and degenerate secondary power. The internal conception motivating the honoring behavior is no longer susceptible of truth or falsity according to some common standard; rather, it is a matter of individual judgment. Even if the honorer values something other than faculties, and even if she is mistaken to think that the thing she values is truly present, her behavior is still honor and still constitutes power. ${ }^{43}$ Furthermore, I argue that this kind of power, where the connection to faculties is likely or certain to be lacking, is central, not merely definitionally but also substantively. It is given systematic privilege in Hobbes's examples of power; the connection to faculties is replaced by a connection to the dispositions of other humans. Reputation is only a tenuous sign of the presence of natural faculties, yet reputation is power "because it draweth with it the adherence of those that need protection" ( $L$ x.5).${ }^{44}$ Indeed more strongly, reputation is a power even when the reputation is contrasted to fact:

$[W]$ hat quality soever maketh a man beloved or feared of many, or the reputation of such a quality, is power. ( $L \mathrm{x} .7$; my emphasis $)^{45}$

Even more strongly again, as is implicit in this quoted passage, the reputation need not even be reputation of having superior faculties; it could merely be a

${ }^{4 \mathrm{r}} \mathrm{This}$ is a term from the later De corpore, referring to those effects that are not related to the causality in question (Hobbes, Elements of Philosophy the First Section, Concerning Body, Chapter IX, Section Io; Latin text in Hobbes and Molesworth, Thome Hobbes Malmesburiensis Opera, Vol. I).

${ }^{42} \mathrm{On}$ this new definition, there is also the change that the characteristic behaviors of placating and propitiating are no longer signs of honor, but they are honor itself.

${ }^{43}$ Strauss observes a change in the relation between honor and power, and specifically the greater role for power; but he interprets this as Hobbes's attempt to hide the humanistic moral basis of his thought (The Political Philosophy of Hobbes: Its Basis and its Genesis, I I 5n2, I69). On my reading, there is no such subterfuge, simply a change in the understanding of the human capacity to achieve ends, as I have argued.

${ }^{44}$ This is also foreshadowed in De cive's theology (DCxv. I3), although not in its political doctrine.

${ }^{45}$ See also $L$ x. 5-6, 8, Iо. 
reputation of superior secondary power $(L \mathrm{x} .38)$. Thus, on the late view, power arises from a reverberation of appearances and reputations in a network of social relations: insofar as the power so generated has effects, it has full status as power.

An example is provided by Hobbes's own canonical model of the commonwealth. In what sense does the sovereign by institution have the same power to enforce covenants as a conqueror? ${ }^{26}$ The sovereign by institution does not possess overwhelmingly superior force as a natural person. However, when soldiers, guards, judges, executioners, and subjects in general play their commanded roles in wielding the metaphorical sword of justice and do not thwart its operation, anyone seeking to disobey will be punished. But why do the soldiers, guards, judges, and executioners do their part even though the sovereign does not personally have a sword to compel them? They do so because each of them believes that every other subject will uphold the command of the sovereign, including wielding its sword as commanded. This network of belief and compliance is a real power for the sovereign, no less than the direct superior force of a conqueror $(L$ xvii. I3 $) .47$ As Hobbes remarks in Behemoth, "[T] he power of the mighty hath no foundation but in the opinion and belief of the people" $(B \mathrm{I} 6)$.

Even if power is often relationally constituted, might there be natural capacities or faculties that count as powers nonrelationally? To the contrary, exercising any capacity in a world populated by other people relies on their conduct, perhaps their aid but at minimum their non-interference. Consequently, in Leviathan all power is socially constituted. This is not the claim that natural faculties or capacities themselves are always socially constituted. Certainly, many capacities do not in themselves need to be understood interpersonally: the capacity to speak many languages, to run a four-minute mile, or to understand the natural world. Rather, the claim is that if (as I have argued) power in Leviathan is human effectiveness toward ends, then even a faculty that is not intrinsically social will only count as a power insofar as it is socially recognized; being dishonored can vitiate the possibility of any natural faculties serving as a means to future apparent goods. For example, Hobbes considers science to be a small power, because even though taken by itself it enormously improves a person's capacity to manipulate the world around her to her ends, it is not recognized as a power: "The sciences are small power, because not eminent, and therefore not acknowledged in any man" ( $L$ x.I4 $)$. It is little use to the scientist to have a capacity to manipulate nature if the people among whom the scientist lives and works thwart her activities. ${ }^{48}$ Superior natural faculties, which might constitute great powers considered in isolated abstraction, are useless in the real social world against well-developed secondary powers. Indeed, the distinction between power and mere faculty is marked from the very start of Leviathan's analysis. Natural faculties are said to be power only insofar as they are

${ }^{46} L$ xvii. I 5 .

${ }^{47}$ Such power, though great, can be fragile: if I suspect others are about to shift their allegiance or otherwise cease upholding the sovereign's power, then I may do so also, so as not to be aligned with a losing force. See my discussion of sedition in section 2.3.

${ }^{48}$ Is this a pointed criticism of Bacon's view of scientific knowledge as power? Knowledge may be power, but it is insignificant in the context of human existence in society. 
eminent $(L \mathrm{x} .2)$ : it is their prominence or conspicuousness that makes them a power, or in other words, the extent to which they are seen by others to be significant.

In Leviathan, Hobbes defines power in general terms: power is the means to "some future apparent good" ( $L$ x.I). Barry Hindess complains that goods are profoundly heterogeneous, and so accordingly are the means to achieve them; consequently Hobbes should not speak of power as though it could be uniformly comparable and homogeneous. ${ }^{49}$ However, attending to the interpersonal context of human action reveals that neither the means nor ends of power are so heterogeneous as Hindess contends. When Hobbes asserts that there is a "perpetual and restless desire of power after power," the ends for the sake of which the power is desired should not be understood to be miscellaneous. The desire of power arises because each "cannot assure the power and means to live well, which he hath present, without the acquisition of more" ( $L$ xi.2). In other words, although I may also desire linguistic capacity in case I should want to converse, grain in case I should want to farm, a lawyer in case I should want to go to court, above all I want the single thing that allows me to live well now and to be able to satisfy whatever desires may arise in the future.

But is there a single thing that supplies this general power, a single means to this general end? My preceding analysis has shown that there is: for humans living in a social world, socially constituted power constitutes a general means to future apparent goods. Allegiance, having people supporting and assisting me in my ends, is a general power because the point of allegiance is to serve the ends of the person to whom allegiance is given, whatever they may be, over an extended period of time, and thereby gain favor. As Hobbes states, "Therefore to have servants is power; to have friends is power; for they are strengths united" $(L \mathrm{x} \cdot 3)$. This observation illuminates the problem with what I called the "positionality claim" of the earlier texts. According to that claim, even if a person's power properly speaking is her natural faculties, her causal effectiveness lies in the superiority of her faculties compared to others. Two competitors race for an apple; if I am the slower runner then I do not get the apple. But speed alone will be the criterion of success only when the race is a well-regulated competition in which the rules are respected. Outside of this special case, my slowness may not prevent me from gaining the apple, for perhaps I have a greater band of friends or supporters willing to help me and obstruct my competitor; or perhaps I have sufficient riches to buy the apple. ${ }^{50}$

To be sure, allegiance is not perfectly general in its effects. A band of lawyer friends does not help in a street fight, nor do streetfighter friends help in court, as Hobbes readily acknowledges ( $L$ x.I 6). However, this imperfection only becomes a major phenomenon when considering specific short-term ends. Allegiance is very close to a general power when it is considered with respect to the enduring

${ }^{49}$ Hindess, Discourses of Power: From Hobbes to Foucault, 24-32.

${ }^{5 \circ}$ For this reason, I cannot accept Macpherson's argument that the relationality at stake in Leviathan is the same as the positionality of earlier texts ("Introduction," 34-35); see also Lazzeri, Droit, pouvoir et liberté: Spinoza critique de Hobbes, 74n I. 
fundamental human end of security and the capacity to pursue future desires unmolested. To return to Leviathan's account of riches, riches do not count as powers because they can be exchanged for specific goods: for Hobbes states that riches are only a power when combined with liberality $(L \mathrm{x} .4)$. Liberality makes no difference to the capacity to carry out direct exchanges, but it does make a difference for allegiance. People desiring to advance or protect their own general power will give the possessor of riches their allegiance insofar as they hope to receive whatever unspecified assistance they may require from those riches in the future. Liberality gives rise to this hope; illiberality quashes it $(L \mathrm{x} .4)$.

It is always possible to restrict one's analysis to consider faculties or capacities in artificial isolation and to abstract away from this looser social context of allegiance: one can always consider the scientist apart from the mob, the race competitors apart from their supporters. This was the procedure of the early texts. But if the phenomenon to be explained under the rubric of power is human effectiveness, and if, as Leviathan's account proposes, allegiance is the central determinant of this effectiveness, then such abstraction vitiates the analysis of power. On this new account, power is neither natural faculties nor any other attribute that could be neatly accommodated as a possession of the individual: human power lies fundamentally in relations. ${ }^{51}$ In contrast to De Cive and The Elements of Law, Leviathan finds an individual's human nature and power to lie outside of her or him, both physically and conceptually, in her or his potentially shifting and relational social context. ${ }^{52}$ Allegiance becomes the fundamental constituent of power: as such, an individual's power may well fluctuate in ways beyond her control.

2.2

Hobbes's new conception of power marks not merely a semantic or definitional change: to the contrary, I now argue that it gives rise to a substantively different social ontology. Where the discussion of power in The Elements of Law stressed the tendency of humans to isolation and fragmentation unless they are brought together in a formal union, now Leviathan's discussion of power brings to the fore an opposite phenomenon. Humans have a constant tendency to form associations, some of which are politically significant even though they are not bound into a union. I argue that in Leviathan's new social ontology, Hobbes envisages an active social domain from which groupings constantly emerge apart from any process of covenant, and in which inequalities are constantly generated..$^{53}$

${ }^{5} \mathrm{~A}$ similar argument is offered by Rudolph. Rudolph argues that from The Elements of Law to Leviathan, Hobbes moves from understanding appetite as a biological attribute to understanding it as socially constituted; correspondingly a move from understanding power as a drive to power as an acquired characteristic ("Conflict, Egoism and Power in Hobbes," 73-88; "The Microfoundations of Hobbes's Political Theory," 34-52).

${ }^{52}$ Against Oakeshott, who claims that Leviathan's science takes the human individual in isolation (Hobbes on Civil Association, 32-34). Foisneau documents another respect in which Leviathan's social theory moves to a more relational analysis: a change from justice understood in Aristotelian terms as commutative or distributive, and injustice as tort, to justice understood as determined by a market, injustice as breach of covenant (Foisneau, "Leviathan's Theory of Justice," I05).

${ }^{53}$ The new social ontology has only occasionally been noted. The work of Tarlton and Frost is truly an exception in this respect; see Tarlton, "The Creation and Maintenance of Government: a Neglected 
There is a curious difference in Leviathan's account of the state of nature compared to the earlier texts. Hobbes still asserts that there is a rough equality among humans. However, this equality is not (as previously) established simply by appeal to the rough similarity of natural faculties. To the contrary, some people are "manifestly stronger" than others. Despite this difference of strength, Hobbes claims that equality of power may be achieved by the weak confederating to counter the strong ( $L$ xiii.I). ${ }^{54}$ This suggests that associations are politically salient, and raises the question, might there also be associations that increase inequality rather than eliminating it?55 Does this variation of wording truly point towards a changed social ontology? The possibility that there is no real difference is suggested by Hobbes's reiteration of his view from The Elements of Law and De Cive that informal associations are so fragile as to be politically inadequate. In Leviathan, Hobbes reasserts that humans lack community compared with animals ( $L$ xvii.6-I 2), and that people in an informal association

can expect thereby no defence, nor protection, neither against a common enemy, nor against the injuries of one another. For being distracted in opinions concerning the best use and application of their strength, they do not help, but hinder one another, and reduce their strength by mutual opposition to nothing; whereby they are easily, not only subdued by a very few that agree together, but also when there is no common enemy, they make war upon each other, for their particular interests. For if we could suppose a great multitude of men to consent in the observation of justice and other laws of nature without a common power to keep them all in awe, we might as well suppose all mankind to do the same; and then there neither would be, nor need to be, any civil government or commonwealth at all, because there would be peace without subjection. $(L \text { xvii.4 })^{56}$

I concede that for Hobbes, humans desire security to "last all the time of their life," and this requires a formal commonwealth; any temporary association around specific momentary purposes does not serve this purpose $(L$ xvii. 5$)$. However, I

Dimension of Hobbes's Leviathan," 307-27; and Frost, Lessons from a Materialist Thinker: Hobbesian Reflections on Ethics and Politics, I 3 I-72. Even those who appreciate the interpersonal character of Hobbes's later conception of power tend to attribute to him a consistent social ontology of power as fragmented and isolated. (See notably Macpherson, "Introduction," 55-56; Montag, Bodies, Masses, Power: Spinoza and His Contemporaries, 90-I03.) Macpherson complains that Hobbes does not anticipate the formation of cohesive classes, and that he focuses too much on centrifugal forces rather than centripetal ones ("Introduction," 55-56; see also "Leviathan Restored: A Reply to Carmichael," 383-85). But in this section, although I concede Hobbes does not consider class formations, I argue that Leviathan ( $L$ $\mathrm{x}$ ) is very interested in centripetal forces. (In this vein, see Carmichael, "Reply: Macpherson Versus the Text of Leviathan," 39I.)

${ }^{54}$ Tarlton, "The Creation and Maintenance of Government: A Neglected Dimension of Hobbes's Leviathan," 3 II. It is common in the literature to miss this distinction, and still to claim equality of power in the state of nature. See for instance Martinich, Hobbes, 26; Pettit, Made with Words: Hobbes on Language, Mind, and Politics, IOI-2; and Read, "Thomas Hobbes: Power in the State of Nature, Power in Civil Society," 5 I 4 .

${ }^{55}$ Hobbes should perhaps have seen this problem for equality even in his earlier texts: for he acknowledges that there are families in the state of nature, and different sized families will have different power (EL II.4.2). However, Hobbes does not make any indication there of being aware of the problem, perhaps because of his methodological abstraction to individuals considered "like mushrooms" (Hobbes, On the Citizen, viii. I).

${ }^{56} \mathrm{In}$ a similar vein, Hobbes characterizes life in the state of nature as "solitary, poor, nasty, brutish, and short" (L xiii.9; my emphasis). 
claim that Leviathan explores a new option for association that lies between a momentary association motivated by specific goals and a formal union for the sake of permanent security. This association oriented toward mid-range goals comes about in a new fashion, which correspondingly endows it with the possibility of durability and political salience, even if not the supreme security of a permanent union.

Leviathan's account of power gives systematically more emphasis to informal associations. In The Elements of Law, the positionality claim pits individual against individual, and the only salient possibility of human coalition is a formal union via covenant, a topic deferred to later in the book (EL I.8.4). By contrast, in the corresponding point in the text of Leviathan, Hobbes replaces the focus on fragmentation with aggregation. ${ }^{57}$ Hobbes asserts that the greatest human power is "strengths united" ( $L \mathrm{x} \cdot 3)$; although one example of strengths united is a commonwealth united by sovereign covenant, he also explicitly countenances a compound of powers "depending on the will of each particular," as for example friendship. That is, the greatest of human powers is achieved not only by a formal union bound by a permanent covenant into a single will; rather, it can also be achieved in an informal association where wills remain separate..$^{8}$

In earlier texts, associations were formed by separate individuals' agreement on specific shared ends. Correspondingly, whether because those ends were superseded or because of other differences or passions, the associations tended to collapse. ${ }^{59}$ Leviathan by contrast envisages an alternative and anthropologically more deeply rooted basis for association. As I argued in section 2.I, individuals perpetually seek power by taking care to placate and propitiate (to honor) those whom they speculate could harm or assist their own ends. They seek to ally themselves in such a way as to advance and protect their ability to live securely and pursue their more specific ends. However, this very same behavior has an effect that is not necessarily intended either by those honoring or those honored: it constitutes patronage networks, security blocs, gangs of followers, and allegiance groups. In other words, the desire for power leads to the spontaneous formation of associations, superseding the rough equality of individuals with the inequality of more or less mighty groupings. ${ }^{60}$ For instance, recall that riches are a power insofar as they garner allegiance ${ }^{61}$ When multiple individuals offer their allegiance to the possessor of riches, an association is constituted.

${ }^{57}$ Both McNeilly and Carmichael observe the account of The Elements of Law envisages universal opposition of powers, whereas Leviathan envisages limited opposition, including the possibility of friendship groupings (Carmichael, "Macpherson's 'Hobbes': A Critique," 36I, 368-69; McNeilly, The Anatomy of Leviathan, I44-47). Most other commentators consider Leviathan's social ontology to be fragmented and isolated; see for instance Hampton, Hobbes and the Social Contract Tradition, 58-79; Oakeshott, "Introduction," xxxiv-xxxv; and Read, "Thomas Hobbes: Power in the State of Nature, Power in Civil Society," 5 I 4.

${ }^{58}$ In the Latin edition, the greatest ( maxima) power is the formal union of wills: a federation where wills remain separate is said to be second in power (proxima). Nonetheless, the point of the English edition still holds: an informal union is a considerable power. Indeed, by contrast in the earlier texts, it was not even possible to attribute a single potentia to an association.

${ }^{59}$ See section I.2.

${ }^{60} L \mathrm{x} .5-9$, x.20, x.38, x.45. Hobbes adds other more specific tendencies relevant to formation of allegiance in his chapter on manners $(L$ xi.4-5, x.7, X.I 6-I 8, X.27).

${ }^{6}$ See section 2.I. 
Furthermore, these associations of allegiance have greater durability than associations for specific ends. The motivating desire of clients in these associations is not tied to transient specific goals, but to the perpetual goal of advancing and protecting their own general power. By consequence, the association so formed is potentially capable of motivating behavior over an extended period of time. Consider now the factors that destabilize associations even among those with durably shared goals, notably envy and disagreement. These do not arise so acutely in spontaneous associations of allegiance and patronage. If I envy my partner in a cooperative enterprise and covet her goods, it may be impossible to continue cooperating; by contrast if I envy the wealth of my patron and covet her goods, I am likely nonetheless to continue to be her client in hope receiving some benefit ( $L$ x.I9, X.23). If I disagree with my patron's decisions but still hope to be favored by her, then I have a strong reason to put my disagreement aside ( $L$ x.28, x.30).

These kinds of association are not merely potentially stable, but they are also potentially very great powers. The Elements of Law asserts the positionality claim: powers cancel out each others' effects. At the corresponding point in Leviathan, Hobbes notes the opposite phenomenon, of accumulation and increase: "For the nature of power is in this point like to fame, increasing as it proceeds; or like the motion of heavy bodies, which, the further they go, make still the more haste" ( $L$ x.2). The mechanism of this self-increase is social. Allegiance is not only a power in itself, but it is also a sign of power. As a sign of power, it attracts honor, very likely in the form of more allegiance. X has a lot of friends, so I want to be her friend; y has henchmen, so I do not want to annoy her; I heard that people plan to back z, so I back z too: in all cases the reputation of holding many people's allegiance leads to ever more people placating and propitiating, or in other words, to a bigger and more solid social grouping ( $L$ x.38).

To be sure, I am not claiming that these associations have a guaranteed stability. The very nature of their constitution carries a deep risk of instability: if my reason for offering my allegiance to a powerful individual or organization is my perception of her power and the likelihood of my benefiting from it, then should that perception change, I will withdraw my allegiance. Worse, given that my estimation of that power may be largely based on the evidence I see of others' opinion of that power, if ever I suspect that others are shifting their allegiance, I will be quick to do the same. But the fact that these associations may be unstable does not prevent them from existing, and under many circumstances proving quite durable. One example that Hobbes considers at length is religious association. Religion can give rise to durable social compounds that do not rely on sovereignty or punitive covenant, although they may subsequently be captured politically ( $L$ xii.I2, I9, 20, 2I 24). ${ }^{62}$ Further examples are seditious associations, and even the power of the sovereign itself, as I will show in section 2.3. These associations break the former equality of power: on the new social ontology, we see a much more uneven texture of social life. Individuals are no longer largely equal in power: some have the allegiance and support of more people than others.

\footnotetext{
${ }^{62} \mathrm{This}$ anthropology of religious association was entirely lacking in the earlier texts.
} 
2.3

In his early texts, Hobbes presumes that the sovereign's punitive incentive will be sufficient to render subjects obedient, and to bring its effective power to meet the power to which it is entitled. In this section, I argue this picture comes under pressure in his later civil science. For the changed social ontology envisages a social sphere much less amenable to decisive unification, and consequently forces a potentially much greater gulf between the sovereign's entitled capacity and its effective capacity. I argue that in Leviathan Hobbes addresses this problem by developing a dual science of politics. ${ }^{63}$ 'Potentia' now refers only to the sovereign's effective capacity and does not purport to illuminate entitled capacity; entitled capacity or authority is now considered separately under the heading of the sovereign's 'potestas' or 'imperium.' ${ }^{64}$ To be sure, the science of potestas is dominant in Hobbes's works, ${ }^{65}$ explaining commentators' neglect of his science of potentia. ${ }^{66}$ However, the development of a distinct science of potentia corresponds to a new understanding of the problem of politics. The challenge for the political philosopher is not merely to establish a science of entitled power elaborated through a doctrine of right blithely assuming that effective power will readily follow; it is also necessary

${ }^{6}$ I concede that Hobbes's explicit taxonomies of science do not list these separately $(L \mathrm{ix})$. However, in Leviathan the two concepts are given distinct systematic treatment, unlike the early texts where they were conflated. Malcolm argues that Hobbes equivocates between understanding cause as the consequences of names and as the consequences of facts; correspondingly he offers two sciences of man confused together (Malcolm, "Hobbes's Science of Politics and His Theory of Science," Aspects of Hobbes, I 55 ). Against this view, I do not find confusion in Hobbes's texts; rather, I agree with Matheron in finding two complementary analyses ("Spinoza et la décomposition de la politique thomiste: Machiavélisme et utopie," 77).

${ }^{6}$ In this light, it is a mistake to characterize Hobbes as the exemplary opponent of constituent power, as do Montag (Bodies, Masses, Power: Spinoza and His Contemporaries, 92-95) and Kalyvas ("Popular Sovereignty, Democracy, and the Constituent Power," 223-44). It is also an error to use analysis of $D e$ cive's Latin as a guide for the terminology in Leviathan, as Silverthorne does ("Political Terms in the Latin of Thomas Hobbes," 506-8).

${ }^{6}$ Especially in De cive, which lacks the elements of the larger system of science of the powers of bodies.

${ }^{66}$ Many commentators simply neglect Hobbes's account of the sovereign's capacity, attributing to Hobbes only a juridical science of potestas (only a science of what ought to occur), for instance: Martinich, Hobbes, 43-53; Pettit, Made with Words: Hobbes on Language, Mind, and Politics, I I 5-40; Spragens, The Politics of Motion: The World of Thomas Hobbes, I I 2-24, I 5 I-5 8; and Tuck, Hobbes, 64-76. However, there are several commentators who supplement their account of Hobbes's juridical science with a direct denial that he has a science of effective power. These include Goldsmith, Hobbes's Science of Politics, 93-2 I 4, especially I76; Hindess, Discourses of Power: From Hobbes to Foucault, 35-39; Johnston, The Rhetoric of Leviathan: Thomas Hobbes and the Politics of Cultural Transformation, 70, I22, 2 I 5 ; Montag, Bodies, Masses, Power: Spinoza and His Contemporaries, 90-103; Oakeshott, "Introduction," xxvii-xxix; Read, "Thomas Hobbes: Power in the State of Nature, Power in Civil Society," 5I4-20; Sorell, Hobbes, 8-2 I; and Strauss, The Political Philosophy of Hobbes: Its Basis and its Genesis, 59-78, I69. Rational-choice readers of Hobbes also only offer an account of authority. Kavka (Hobbesian moral and political theory, xiii, I9-20) reconstructs Hobbes's "descriptive" theory of politics, as an account of what ideally rational agents would do. He then faults Hobbes for not giving an account of irrationality in his descriptive theory (438). But as I will argue, Leviathan's account of the sovereign's capacity power offers just such a descriptive theory; Kavka's theory lies closer to the entitled capacity theory, which is what subjects would do if they always had sufficient rationality to obey. (See also Hampton, Hobbes and the Social Contract Tradition, I73-88.) 
to understand the real determinants of effective power as systematically and precisely as possible, in order to bring that effective power to coincide with right. ${ }^{67}$

Hobbes's civil science seeks to explain the establishment and maintenance of peace and security. If the sovereign has power in accord with its entitlement (that is, if there is obedience), peace is achieved. If there is disobedience, the sovereign has less capacity than that to which it is entitled. Should there be a great deal of disobedience, the civil order degenerates into anarchy and war. Nonetheless, in the early texts civil science takes the form of a science of the sovereign's power (potentia) as a fictional person: an analysis of potentia as sovereign's faculties (its entitled capacities from subjects), and not its effective capacity. Hobbes does not offer any systematic account of the sovereign's effective capacity insofar as that may diverge from the capacities to which it is entitled. This is acceptable, because Hobbes claims that the sovereign will in fact have effective capacity commensurate to its right. First, he anticipates that in the face of the punitive incentive, subjects will generally hand over their power to the sovereign in accord with its right. ${ }^{68}$ Second, the threats to the sovereign's power are easily identified and controlled. The social order is understood as one of flat, fragmented equality of power among subjects, with no individual having sufficient power to challenge the sovereign. The only way in which the sovereign order is threatened is when subjects deliberately form a faction for the purpose of overthrowing the sovereign. Correspondingly, the commonwealth is secure so long as it can prevent the formation of such unions. ${ }^{69}$ Thus although the science of the sovereign's potentia provides an account of sovereign's entitlement to rather than its achievement of obedience, divergence between these two will not be too grave.

In the view of the later text, Leviathan, there is a different and much graver threat to the commonwealth..$^{\circ}$ It is posed by groupings that are mere associations, not unions, and that are not formed with seditious intent, but that simply emerge according to the spontaneous dynamics of the pursuit of power outlined in section 2.2. Hobbes shows a new and persistent concern with eminent individuals, the immoderate greatness of towns, and the accumulation of treasure by monopolies or farms ( $L$ xxii.3 I-32, xxvii, xxix.I9, xxix.2I). The presence and perpetual emergence of informal associations is newly recognized in Leviathan as a political fact to be dealt with, even though such associations fail in Hobbes's view to provide a tenable alternative to sovereign rule. This concern is further developed in Behemoth, in which the wealth, influence, and popular support of religious groupings and great towns are identified as the matrix of England's descent into civil war $\left(B_{3}-4\right)$.

${ }^{67}$ Frost's analysis (with which I am otherwise sympathetic) is hampered by presuming a single unified use of the English term 'power,' and not observing its correspondence to the systematic Latin distinction between potentia and potestas. She gives an excellent account of power as capacity, but presumes this also directly accounts for the sovereign's authority or rightful power; see Lessons from a Materialist Thinker: Hobbesian Reflections on Ethics and Politics, I 3 I-72.

${ }^{68} \mathrm{As}$ I argued in section I.3.

${ }^{69}$ As I argued in section I.2.

${ }^{70} \mathrm{Johnston}$ also finds a change in the sovereign's vulnerability: he argues the sovereign finds itself more sensitive to opinion (The Rhetoric of Leviathan: Thomas Hobbes and the Politics of Cultural Transformation, 78-80). 
There are two reasons why these groups pose a problem, even though they are not formed for the sake of sedition. First, they provide means for sedition, if the intent does arise. In the early texts, the means of sedition are only secured after an active decision to form a faction for the purpose of sedition. In Leviathan, the means (power blocs not dependent on the sovereign's pleasure) are always being generated, even without any seditious intent. Thus, should an ambitious individual develop seditious plans, they may already have at their disposal the means to put these plans into action; it will be that much more difficult for the sovereign to arrest these plans.

$[\mathrm{P}]$ opularity of a potent subject (unless the commonwealth has very good caution of his fidelity) is a dangerous disease, because the people (which should receive their motion from the authority of the sovereign), by the flattery and by the reputation of an ambitious man, are drawn away from their obedience to the laws, to follow a man of whose virtues and designs they have no knowledge. ( $L$ xxix.20)

The second reason why these groups are dangerous to the sovereign is even more serious. The existence of other powers within the social order in itself means the sovereign has less effective capacity. Powerful subjects tend to engage in the commonplace pursuit of advantage; they do not in general have the intent to seize power or to destroy the civil order, but they do want to have things their way. In particular, they think they ought not be punished, and hope to escape punishment.

And that such as have multitude of potent kindred, and popular men, that have gained reputation amongst the multitude, take courage to violate the laws from a hope of oppressing the power to whom it belongeth to put them in execution. ( $L$ xxvii.I 5 )

The sovereign knows that when it wants to issue or enforce some command that is inconvenient to the powerful subject, it cannot presume it will secure obedience from that subject, and perhaps not from the subject's supporters either. For the powerful subject and her or his followers have the power simply not to comply. They may comply in some cases, they may limit their reaction to noncompliance, or they may be provoked into hostile retaliation to teach the sovereign not to trespass on their concerns. This is vividly illustrated by King Charles I's abortive attempts to impose the Book of Common Prayer on Scotland and to demand Ship Money ( $B 28-30,36-37)$. In all cases, the sovereign's power is weakened. It cannot simply ignore the fact of powerful subjects in society and make no concessions to them, because any successful display of disobedience publicizes the subject's power and gains her or him even more allegiance. For this reason, crime from presumption of strength giving impunity is much more politically pernicious than the everyday crime from hope of not being discovered ( $L$ xxvii.30).

However, no alternative response from the sovereign is clearly better. For if the sovereign acknowledges the limits on its own effective power, it is drawn into a game of appeasement, which can only end badly. The sovereign may bestow benefits on a subject (whether exempting from punishment or making policy to please) "for fear of some power and ability he hath to do hurt to the commonwealth" ( $L$ xxviii.25). Such benefits are "extorted by fear" and are in this sense sacrifices that the sovereign "makes for the appeasing of the discontent of him he thinks more potent than himself" ( $L$ xxviii.25). However, this strategy does not encour- 
age obedience; quite the opposite, it encourages increased extortion, as Charles I found after his attempts to appease the Scots and parliament backfired ${ }^{7 \mathrm{~T}}(B$ 75-76, 97-IO2, I I 5). For achieving the deference of the sovereign makes visible the subject's power, garnering more allegiance. Seeing the sovereign's weakness emboldens others to press for concessions too. This may defer civil war, "yet the danger grows still the greater, and the public ruin is more assured" ( $L \mathrm{xxx} .24)$.

The lesson from this analysis is a dispiriting one. Power groups, once established, cannot necessarily be eviscerated without negative consequences. Instead, powerful subjects need to be cut down before their influence grows ( $L$ xxx.24). The problem is that this will be very difficult to achieve. First, Hobbes says subjects should be prevented from honoring fellow subjects, for this would constitute unequal powers not subject to the control of the sovereign $(L \mathrm{xxx} .8)$. But almost all social conduct has a valence as honor or dishonor, and so it will be impossible to eliminate honor entirely ( $L$ x.19-36). Second, functionally, not all power differences can be suppressed. The commander of the army needs to be popular to do his job, even though this is a danger to the sovereign ( $L$ xxx.28). Hobbes suggests that the sovereign can minimize the danger from the popularity of a subject by itself being popular ( $L \times x \times .29)$. But it is not clear how to become popular if that status is not already secured; for as already discussed, granting benefits extorted by fear is a highly dangerous political strategy, and pandering to the people does just this ( $L$ xxviii.25).

Thus, the new social ontology shows that the sovereign will face a constant need to maintain its power in the face of spontaneously emergent powers in the populace; such powers are a threat even when they have no seditious intent. ${ }^{72}$ While a sovereign can take measures to try to deflate and level out such powers, this will be an ongoing task for which success is uncertain. The result is that it is a challenge for the sovereign to achieve actual effective capacity commensurate to its entitlement; peace is not so easily or definitively achieved as it was in the earlier texts.

The sovereign's entitled power and effective power may diverge; this would be a problem for Hobbes's science of the sovereign's power as capacity (potentia) if it still attempted, as in the early texts, to illuminate the sovereign's effective capacity to secure peace by laying out the sovereign's fictional faculties (its entitled capacity). Now in Leviathan, there is an obvious alternative strategy. For the new concept of individual human power (potentia) as effective capacity can immediately be extended to the sovereign. On the new account of individual human power, obedience is itself a prime constituent of power, rather than simply a recognition of a power (faculties) that exists independently as I argued in section 2.I. Whenever one individual obeys another's command, she gives power to the one she obeys $(L \times .20)$. To extend this analysis to the sovereign, all that is required is to consider the sovereign commander as just another person being obeyed, rather than in its fictional juridical nature. In this case, the potentia of the sovereign is a

\footnotetext{
${ }^{71}$ To be sure, Hobbes says the parliament also actively desired to usurp sovereignty.

${ }^{72} \mathrm{I}$ concede that $\mathrm{De}$ cive already displays an incipient worry with emergent powers even when they are not deliberately for the purpose of sedition $(D C \mathrm{x} .7)$. However, De cive awkwardly analyses this still in the language of formal unions, which is unconvincing for examples such as popularity and wealth (DC xiii.I3).
} 
variable property: the capacity that it exercises through whatever actual obedience of subjects it is able to garner.

To be sure, there is a difference between the sovereign and any other figure that finds itself obeyed. For the sovereign is entitled to the obedience of subjects ( $L$ xvii.I3-I4). Even if in fact its potentia is limited by a disobedient populace, it is entitled to have the greater potentia that would correspond to their obedience. ${ }^{73}$ Indeed, Hobbes understands the sovereign's behavior in appeasing powerful subjects as its behavior qua natural individual; this is contrasted with its power as the person of the commonwealth, by which it is entitled to obedience ( $L$ xxviii.25). The sovereign is so entitled not only because obedience has been promised to it through covenant, but also more importantly because natural law stipulates that such a covenant is needed for peace $(L$ xiv.4-5). Indeed, the early science of the sovereign's power as a science of entitlement is retained, but now under heading of potestas/imperium. It is still very important to get this correct: Hobbes places first in his list of causes of the dissolution of the commonwealth the sovereign resting "content with less power [potestas] than to the peace and defence of the commonwealth is necessarily required" ( $L$ xxix.3).

The transformation of Hobbes's treatment of power has far-reaching consequences for his science of politics. Juridical arguments may generate an account of right and authority, but a cursory appeal to punitive incentives is insufficient to establish the possibility that political order under such a juridical model could stably exist. Where De Cive asserts that all commonwealths alike possess a stable potentia that is equated with their imperium, now the corresponding passage in Leviathan raises the concern that despite its stable potestas, a commonwealth might suffer a diminished potentia ( $D C$ x.I6, $L$ xix.4). In the later texts, establishing the correct doctrine of juridical potestas/ imperium now needs to be distinguished from and supplemented by a difficult and quite separate analysis of how the concretely causal potentia to which the sovereign is entitled is to be achieved and sustained. Effective power is no longer conceived as a stable possession but as a variable and relationally constituted effective capacity. This transformed conception of power illuminates the domain of lived politics below the neat categories of the juridical sphere, promising to offer a better understanding of actual dynamics of political stability, and what threatens it. ${ }^{74}$

\section{NOTE ON HOB B ES'S TEXTS}

Where possible, I have avoided using the Molesworth English Works / Opera Latina editions of Hobbes's writings, given the inadequacies of those texts. (See discussion in Warrender, "Editor's Introduction," v, 34; Tuck, "Introduction," On the Citizen, xlviii; Curley, "Introduction to Hobbes' Leviathan," lxxi.)

${ }^{73}$ I stress, contra Frost (see n. 67) that authority or entitled power (potestas) does not collapse into effective power (potentia). It is true, as Hoekstra shows ("The De Facto Turn in Hobbes's Political Philosophy," 33-35), that sufficient effective power grants sovereign authority (imperium/summa potestas) and insufficient effective power removes it. However, so long as effective power does not fluctuate below a certain threshold, the authority or entitled power of the sovereign remains stable.

${ }^{74}$ I gratefully acknowledge support for this research from the Stafford Fund of the Princeton University Department of Politics, and from an American Political Science Association Travel Grant. 
Although Hobbes's language is gendered, his conceptual analysis is to a remarkable degree ungendered, particularly by comparison with other canonical figures from the history of political thought (for instance, consider Hobbes's refusal to naturalize the authority of men over women [ $L$, chapter xx, sections 4-5]). Correspondingly, while for the sake of exegetical clarity I make some concession to the original Hobbesian terminology (for instance, retaining 'science of man'), otherwise I will frequently reformulate Hobbes's arguments in gender neutral terms.

\section{B I B L I O G R A P H Y A N D A B B R E V I A T I O N S}

Anstey, Peter R. "Experimental Versus Speculative Natural Philosophy." In The Science of Nature, in the Seventeenth Century: Patterns of Change in Early Modern Natural Philosophy, edited by Peter R. Anstey and John A. Schuster, 219-42. Dordrecht: Springer, 2005.

Baumgold, Deborah. Hobbes's Political Theory. New York: Cambridge University Press, I988.

Brandt, Frithiof. Thomas Hobbes's Mechanical Conception of Nature. Copenhagen: Levin \& Munksgaard, I928.

Carmichael, D. J. C. “C. B. Macpherson's 'Hobbes': A Critique.” In King, Thomas Hobbes: Critical Assessments, 359-79.

_. "Reply: Macpherson Versus the Text of Leviathan." In King, Thomas Hobbes: Critical Assessments, 390-92.

Curley, Edwin. "Introduction to Hobbes' Leviathan." In Hobbes, Leviathan: With Selected Variants from the Latin Edition of I 668, viii-lxxvii.

Foisneau, Luc. Hobbes et la toute-puissance de Dieu. Paris: Presses Universitaires de France, 2000. "Leviathan's Theory of Justice." In Sorell and Foisneau, Leviathan after 350 Years, 105-22.

Frost, Samantha. Lessons from a Materialist Thinker: Hobbesian Reflections on Ethics and Politics. Stanford: Stanford University Press, 2008.

Goldsmith, M. M. Hobbes's Science of Politics. New York: Columbia University Press, I 966.

Hampton, Jean. Hobbes and the Social Contract Tradition. Cambridge: Cambridge University Press, I986.

Hindess, Barry. Discourses of Power: From Hobbes to Foucault. Oxford: Blackwell Publishers, 1996.

Hobbes, Thomas. Behemoth, or the Long Parliament. Edited by Ferdinand Tönnies. London: Simpkin, Marshall, and Co., I 889. [B]

- De cive. Edited by Howard Warrender. Oxford: Clarendon Press, 1983. [DC]

. The Elements of Law, Natural and Politic. Edited by Ferdinand Tönnies. London: Cass, I969. [EL]

. Elements of Philosophy, The First Section, Concerning Body. London: Printed by R. \& W. Leybourn, for Andrew Crocke, at the Green Dragon in Pauls Church-yard, I656.

- Leviathan: With Selected Variants from the Latin Edition of I668. Edited by Edwin Curley. Indianapolis: Hackett, I994. [L]

. "On Man." In Thomas Hobbes, Man and Citizen, edited by Bernard Gert, 33-87. Garden City, N.Y.: Anchor Books, I972.

- On the Citizen. Translated by Richard Tuck and Michael Silverthorne. Edited by Richard Tuck and Michael Silverthorne. Cambridge: Cambridge University Press, 2006.

Hobbes, Thomas, and William Molesworth. Thome Hobbes Malmesburiensis Opera Philosophica Qua Latine Scripsit Omnia, in Unum Corpus Nunc Primum Collecta Studio Et Labore Gulielmi Molesworth. Londini: apud Joannem Bohn, I 839. [Thoma Hobbes Malmesburiensis Opera]

Hoekstra, Kinch. "The De Facto Turn in Hobbes's Political Philosophy." In Sorell and Foisneau, Leviathan after 350 Years, 33-73.

Johnston, David. The Rhetoric of Leviathan: Thomas Hobbes and the Politics of Cultural Transformation. Princeton, NJ: Princeton University Press, I986.

Kalyvas, Andreas. "Popular Sovereignty, Democracy, and the Constituent Power." Constellations I 2 (2005): 223-44.

Kavka, Gregory S. Hobbesian Moral and Political Theory. Princeton, NJ: Princeton University Press, I986.

King, Preston, ed. Thomas Hobbes: Critical Assessments. Vol. I. London: Routledge, 1993.

Lazzeri, Christian. Droit, pouvoir et liberté: Spinoza critique de Hobbes. Paris: Presses Universitaires de France, I998.

—. "Les racines de la volonté de puissance: le 'passage' de Machiavel à Hobbes." In Thomas Hobbes: Philosophie première, théorie de la science et politique, edited by Yves Charles Zarka and Jean Bernhardt, 
225-46. Paris: Presses universitaires de France, I990.

Macpherson, C. B. "Introduction." In Thomas Hobbes, Leviathan, edited by C. B. Macpherson, 9-63. London: Penguin, I985.

. "Leviathan Restored: A Reply to Carmichael." In King, Thomas Hobbes: Critical Assessments, 380-89. . The Political Theory of Possessive Individualism: Hobbes to Locke. Oxford: Clarendon Press, I962.

Malcolm, Noel. "Hobbes's Science of Politics and His Theory of Science." In Noel Malcolm, Aspects of Hobbes, I46-5 5. Oxford: Clarendon, 2002.

Martinich, A. P. Hobbes. New York: Routledge, 2005.

Matheron, Alexandre. "Spinoza et la décomposition de la politique thomiste: Machiavélisme et utopie." In Anthropologie et politique au xviie siècle: Études sur Spinoza, 49-79. Paris: J. Vrin, I986.

McNeilly, F. S. The Anatomy of Leviathan. London: Macmillan; St. Martin's Press, I 968.

Montag, Warren. Bodies, Masses, Power: Spinoza and His Contemporaries. London: Verso, I999.

Oakeshott, Michael. Hobbes on Civil Association. Oxford: Blackwell, I975. . "Introduction." In Thomas Hobbes, Leviathan, i-lxvii. Oxford: Blackwell, I946.

Pettit, Philip. Made with Words: Hobbes on Language, Mind, and Politics. Princeton, NJ: Princeton University Press, 2008.

. "Rawls's Political Ontology." Politics, Philosophy and Economics 4 (2005): I 57-74.

Read, James H. "Thomas Hobbes: Power in the State of Nature, Power in Civil Society." Polity 23 (I99I): 505-25.

Rudolph, Ross. "Conflict, Egoism and Power in Hobbes." History of Political Thought 8 (I986): 73-88. . "The Microfoundations of Hobbes's Political Theory." Hobbes Studies 6 (I99I): 34-52.

Schuhmann, Karl. "Leviathan and De cive." In Sorell and Foisneau, Leviathan after 350 Years, I3-32.

Shapin, Steven, Simon Schaffer, and Thomas Hobbes. Leviathan and the Air-Pump: Hobbes, Boyle, and the Experimental Life: Including a Translation of Thomas Hobbes, Dialogus Physicus De Natura Aeris by Simon Schaffer. Princeton, NJ: Princeton University Press, I985. [Leviathan and the Air-Pump]

Silverthorne, Michael. "Political Terms in the Latin of Thomas Hobbes." International Journal of the Classical Tradition 2 (I996): 499-509.

Sorell, Tom. Hobbes. London: Routledge \& Kegan Paul, I986.

Sorell, Tom, and Luc Foisneau, eds. Leviathan after 350 Years. Oxford: Clarendon, 2004.

Spragens, Thomas A. The Politics of Motion: The World of Thomas Hobbes. Lexington: University Press of Kentucky, I973.

Strauss, Leo. The Political Philosophy of Hobbes: Its Basis and Its Genesis. Translated by Elsa M. Sinclair. Chicago: University of Chicago Press, I96I.

Tarlton, Charles D. "The Creation and Maintenance of Government: A Neglected Dimension of Hobbes's Leviathan." Political Studies 26 (1978): 307-27.

Tuck, Richard. Hobbes. Oxford: Oxford University Press, I989.

. "Introduction." In Thomas Hobbes, Leviathan, edited by Richard Tuck, ix-xcii. Cambridge: Cambridge University Press, I996.

. "Introduction." In Hobbes, On the Citizen, viii-lii.

. "The Utopianism of Leviathan." In Sorell and Foisneau, Leviathan after 350 Years, I25-38.

Warrender, Howard. "Editor's Introduction." In Hobbes, De cive, I-67.

. The Political Philosophy of Hobbes: His Theory of Obligation. Oxford: Clarendon Press, I957.

Watkins, John W. N. Hobbes's System of Ideas: A Study in the Political Significance of Philosophical Theories. London: Hutchinson, I965.

Zarka, Yves Charles. Hobbes et la pensée politique moderne. Paris: Presses Universitaires de France, I995. 


\section{New from Liberty Fund}

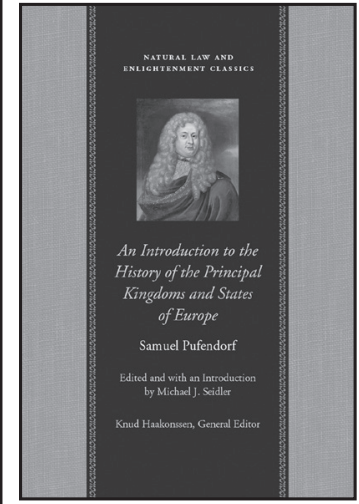

September 2013.

$6 \times 9.768$ pages.

Editor's introductory essay, note on the text, editor's footnotes, appendixes, bibliography, index.

Cloth. $\$ 24.00 / £ 19.95 / C \$ 30.00$. ISBN 978-0-86597-512-5.

Paperback. $\$ 14.50 / £ 10.95 / C \$ 18.00$. ISBN 978-0-86597-513-2.

\section{An Introduction to the History of the Principal Kingdoms and States of Europe}

\section{By Samuel Pufendorf}

Translated by Jodocus Crull (1695)

Edited and with an Introduction by Michael J. Seidler

\section{Dufendorf's An Introduction to the History of the Principal Kingdoms and States of Europe} (1682) became one of his most famous and widely reprinted works. It went through a multitude of editions during the eighteenth century, but its impact has largely been forgotten.

Pufendorf's histories exhibited the core notions of his natural law theory by recounting the development and current, reciprocal relations of individual states as collective social agents engaged in securing their own and, thus, their members' interests, including self-preservation.

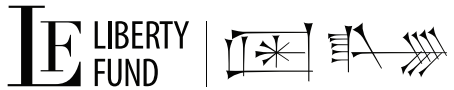

For U.S., South America, Central America, Caribbean:

Phone: (800) 955-8335 (USA) or (317) 348-4676

Fax: (708) 534-7803

Email: libertyfund@ware-pak.com

Web site: www.libertyfund.org

Find us on Facebook at www.facebook.com/LibertyFundBooks

Follow us on Twitter: @Liberty_Fund
For Canada:

Scholarly Book Services

Tel: $\quad$ (800) 847-9736

Fax: (800) 220-9895

E-mail: customerservice@sbookscan.com

For all other regions:

Gazelle Academic

Tel: $\quad+44(0) 152468765$

Fax: $\quad+44(0) 152463232$

E-mail: sales@gazellebooks.co.uk

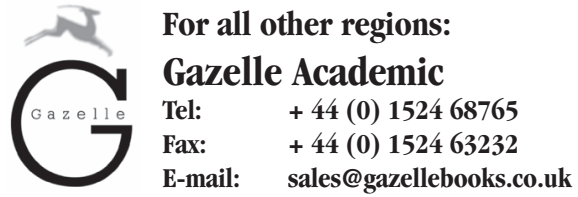

